Karl Möbius, in his very interesting lecture on the."psychischer Horizont der Thiere," figures the animal of Mya arenaria, which has unequal valves, and represents it as sunk perpendicularly in the sand. It would be very desirable that any body having the opportunity of observing the bivalve Mollusca in their living state should examine into the truth of this theory, and record the exceptions.

\title{
The Skeleton of Sphargis coriacea from Surinam.
}

By Dr. Ferdinand Krauss.

I have compared the adult skeleton in the Stuttgart Museum from Surinam with the figures of the skeleton of the French specimen in the 'Archives du Muséum.' I can find no difference between them ; but I notice that no account of the length of the Paris specimen is given, so that we do not know if it is an adult or a young one.

The Surinam specimen in the Stuttgart Museum measures in a straight line, from the end of the skull to the tip of the tail, 187 centims.; the skull is 25 centims. long and 21.5 centims. broad, the fore foot (humerus to the point of the digit) 87 centims., hind foot 66 centims.

\section{The Deal-fish (Trachypterus arcticus).}

In the Report of the Montrose Natural-History and Antiquarian Society for 1873 there is the description of a Vaagmaer or deal-fish, found on the beach at Buddin Bay, near Montrose, and presented to the Society by Joseph Johnston and Sons. The description is accompanied by a very good photograph, $8 \frac{1}{2}$ inches long. The Society's specimen appears to be the T. arcticus of Nilsson and Günther.

Damonia unicolor, a new Species of Water-Tortoise from China, sent by Mr. Swinhoe. By Dr. J. E. Gray, F.R.S. \&c.

Mr. Swinhoe has sent a number of tortoises in spirits from Shanghai. They consist of :-

1. Several specimens of Landemania perocellata, all young; but Mr. Swinhoe says that it grows to the length of $2 \frac{1}{2}$ to 3 feet.

2. Several specimens of Damonia Reevesii, most being of adult age, some being even between 4 and 5 inches long, larger than the adult specimen described by me in the Ann. \& Mag. Nat. Hist. 1873, xi. p. 299.

They all have the shell of a nearly uniform pale brown colour, and are black beneath. The head is large and broad, uniform olive above, with a white streak from the middle of the back of the eye, which forks on the cheek, the upper branch being continued along the side of the neck, the lower branch forked again in front of the tympanum, with the upper branch reflexed and the lower arched; but the form of these lines is not important, as they vary on two 


\section{$2 \mathrm{BHL}$ Biodiversity Heritage Library}

1873. "The deal-fish (Trachypterus arcticus)." The Annals and magazine of natural history; zoology, botany, and geology 12, 77-77.

https://doi.org/10.1080/00222937308680708.

View This Item Online: https://www.biodiversitylibrary.org/item/54290

DOI: https://doi.org/10.1080/00222937308680708

Permalink: https://www.biodiversitylibrary.org/partpdf/53553

\section{Holding Institution}

Smithsonian Libraries

\section{Sponsored by}

Smithsonian

\section{Copyright \& Reuse}

Copyright Status: Public domain. The BHL considers that this work is no longer under copyright protection.

This document was created from content at the Biodiversity Heritage Library, the world's largest open access digital library for biodiversity literature and archives. Visit BHL at https://www.biodiversitylibrary.org. 